\title{
SELECTION AND PROBIOTIC CHARACTERIZATION OF EXOENZYME-PRODUCING BACTERIA ISOLATED FROM THE GUT OF CATLA CATLA (ACTINOPTERYGII: CYPRINIFORMES: CYPRINIDAE)
}

\author{
Dipanjan DUTTA, Sudeshna BANERJEE, Anjan MUKHERJEE, and Koushik GHOSH*
}

Aquaculture Laboratory, Department of Zoology, The University of Burdwan, Golapbag, Burdwan, West Bengal, India

Dutta D., Banerjee S., Mukherjee A., Ghosh K. 2015. Selection and probiotic characterization of exoenzyme-producing bacteria isolated from the gut of Catla catla (Actinopterygii: Cypriniformes: Cyprinidae). Acta Ichthyol. Piscat. 45 (4): 373-384.

Background. Exoenzyme-producing gut microbiota and their likely use as probionts have been widely investigated in major carps. However, reports on exoenzyme-producing capacity together with inhibition of fish pathogens are scarce. The presently reported study aimed at characterization of novel probionts from the gastro-intestinal (GI) tract of an Indian major carp - catla, Catla catla (Hamilton, 1822) depending upon extracellular enzyme-production, antagonism against Aeromonas spp., growth in fish mucus, bile tolerance, and bio-safety to the target fish. Materials and methods. GI tracts were divided into proximal and distal parts, homogenized, and plated onto selective media plates following enrichment culture technique. Exoenzyme-producing isolates were selected through qualitative and quantitative assay of 6 enzymes. Inhibition of Aeromonas spp. was tested through 'cross-streaking' and 'double-layer' method. Tolerance to GI condition was determined by growth in sterilized fish mucus and exposure to bile juice. Bio-safety evaluation was done by intra-peritoneal injection of live candidate probiotics and co-culture with autochthonous gut bacteria. Further, 16S rDNA fragments from the putative probiotics were sequenced, edited, analysed, identified, and deposited to the GenBank.

Results. Seventeen potent isolates were primarily selected through the ability of producing extracellular enzymes, viz., amylase, protease, lipase, cellulase, phytase, and xylanase. Further study portraying antagonism against Aeromonas salmonicida, A. hydrophila, and A. veronii led to select the strains CCH1A and CCH1Ph as putative probiotics. Both the strains were competent to grow in intestinal mucus and could resist diluted bile juice $(9 \%$ and $10.5 \%$, respectively). The isolates did not produce any disease symptom or mortality in Catla catla fingerlings during the 21 day trial and were competent to grow with other autochthonous isolates. On the basis of phenotypic characteristics and 16S rDNA sequence analysis, the strains CCH1A and CCHIPh were identified as Bacillus aerius (KF623288) and Bacillus sonorensis (KF623289), respectively.

Conclusion. Exoenzyme-producing gut bacteria may inhibit the growth of pathogenic Aeromonas spp. and tolerate gastrointestinal condition. Further research is inevitable to explore their potentialities in aquaculture.

Keywords: Indian major carp, Bacillus, extracellular enzyme, antagonism, pathogen

\section{INTRODUCTION}

The last decade has seen a growing interest in the application of probiotics through the use of beneficial microorganisms to improve the nutritional properties of feed (Verscheure et al. 2000) and to reduce the incidence of fish diseases by inhibiting the growth of pathogenic microorganisms (Balcázar et al. 2006, Kesarcodi-Watson et al. 2008). High stocking density of fish under intensive or semi-intensive culture conditions leads to increased feed ration and waste generation with simultaneous increase in organic load and bacterial multiplication (Lio-Po and Lim 2014). Motile aeromonads, being the major bacterial pathogens among warm-water freshwater fish species are reported to be the main caus- ative factor behind mass mortalities of the Indian major carps, i.e., catla, Catla catla (Hamilton, 1822); rohu, Labeo rohita (Hamilton, 1822); and mrigal, Cirrhinus mrigala (Hamilton, 1822) (see Karunasagar et al. 1986). Moreover, Catla has been found to be the most susceptible to Aeromonas infection among the Indian major carps in several previous occasions (Khatri et al. 2009). Aeromonas spp. outbreaks in aquaculture are common in tropical countries and therefore use of antimicrobial drugs has been suggested as prophylactic measure in some of the previous reports (Karunasagar et al. 1986, Mukherjee 1991). However, indiscriminate use of antibiotics has been blamed for the emergence of antibiotic re- 
sistant bacteria in aquaculture (Akinbowale et al. 2006). Several countries have introduced restrictions for antibiotic usage in aquaculture production (Kesarcodi-Watson et al. 2008). Alternatively, probiotics have been proposed as biological control agents to confer benefits to the host fish species. Enzymatic properties of aerobic (Bairagi et al. 2002) and anaerobic (Ramirez and Dixon 2003) intestinal bacteria isolated from diverse fish species have been shown as the potential role a probiotic organism may play. However, enzymatic potential along with antagonistic properties against the potential fish pathogens have been less studied (Sivasubramanian et al. 2012, Luo et al. 2014, Marlida et al. 2014, Dutta and Ghosh 2015).

A number of essential properties could be tested while searching for an effective probiont. A putative probiont should be able to colonize well in the gastrointestinal (GI) tract of the host fish species in order to reveal its beneficial effects. Adherence to mucosal layer of intestinal surface (Nikoskelainen et al. 2001, Balcázar et al. 2008), growth on fish mucus and tolerance to the bile juice are the essential attributes that a candidate probiont should possess (Mukherjee and Ghosh 2014). Antibiotic susceptibility is another important criterion because of the rapid emergence of antibiotic resistance of microorganisms in aquaculture (Ruban and Gunaseelan 2011). In addition, the putative probiotic should not be harmful to the resident or autochthonous gut bacteria as well as to the host (Verscheure et al. 2000).

Hence, the aim of the presently reported study was to isolate and screen novel probiotic bacteria from an Indian major carp, catla, Catla catla, based on their ability to produce different extracellular enzymes, and also to verify other probiotic properties, e.g., antimicrobial activity against Aeromonas spp., growth in fish mucus, resistance to bile, safety evaluation for the target fish and interaction with the normal gut flora.

\section{MATERIALS AND METHODS}

Collection and processing of sample. Nine specimens of catla, Catla catla (mean live weight $375 \pm 10.97 \mathrm{~g}$ ) with no external disease symptoms (Smith et al. 2002) were collected from three composite carp culture ponds located around Burdwan $\left(23^{\circ} 24^{\prime} \mathrm{N}, 87^{\circ} 86^{\prime} \mathrm{E}\right)$, West Bengal, India. The specimens were brought to the laboratory with oxygen packing and distributed separately over 3 fibre-reinforced plastic (FRP) aquaria of $350 \mathrm{~L}$ each on the basis of their source. The ranges of water quality parameters during the collection period were: temperature $26.2-27.8^{\circ} \mathrm{C}$, $\mathrm{pH} 7.1-7.6$, and dissolved oxygen $6.2-7.6 \mathrm{mg} \cdot \mathrm{L}^{-1}$.

The fish were starved for $48 \mathrm{~h}$ in order to clear their GI tracts and anaesthetized by applying $0.03 \%$ tricaine methanesulfonate (MS-222) prior to sacrifice. Ventral surfaces were sterilized using $70 \%$ ethanol and fish were dissected aseptically to remove the GI tract (Ghosh et al. 2010). Gut samples were processed according to Mandal and Ghosh (2013) for isolation of autochthonous microorganisms. The GI tracts were divided into proximal (PI) and distal (DI) parts, flushed thoroughly with normal saline solution (NSS; $0.9 \% \mathrm{NaCl}, \mathrm{w} / \mathrm{v}$ ), and cut into small pieces. Gut segments from three specimens of Catla catla collected from a single pond were pooled together region-wise for each replicate and thus there were three replicates for the study. Gut segments for each replicate was homogenized independently with sterilized chilled $0.9 \%$ phosphate buffered saline (1:10, w/v; $\mathrm{pH}$ 7.0). Pooled sample of 3 fish were used for each replicate to avoid erroneous conclusions due to individual disparity in gut microbiota (Mandal and Ghosh 2013).

Microbial culture. Homogenates of the pooled gut segments were serially $(1: 10)$ diluted in NSS (Beveridge et al. 1991) and poured aseptically $(0.1 \mathrm{~mL})$ onto sterilized Soyabean Casein Digest (Tryptone Soya Agar, TSA; HiMedia, Mumbai, India) media plates to determine the autochthonous culturable heterotrophic aerobic/facultative anaerobic bacteria population. In order to isolate and enumerate diverse extracellular enzyme-producing (e.g., amylase, protease, lipase, cellulase, xylanase, and phytase) bacteria, the diluted gut homogenates were plated onto starch (ST), peptone-gelatin (PG), tributyrin (TB), carboxymethylcellulose $(\mathrm{CMC})$, xylan (XY), and modified phytase screening (MPS) media plates following enrichment culture technique. The culture plates were incubated at $30^{\circ} \mathrm{C}$ for $48 \mathrm{~h}$, bacteria colonies were determined following dilution plate count method and mean values of the replicates were expressed as $\log$ viable count $\cdot \mathrm{g}^{-1}$ GI tract (LVC) (Mandal and Ghosh 2013). The well-separated colonies were randomly collected, streaked individually on respective media plates and re-streaked repeatedly to acquire pure cultures. Pure cultures were maintained on slants in a refrigerator $\left(4^{\circ} \mathrm{C}\right)$ for further study.

Media composition. ST media $\left(\mathrm{g} \cdot \mathrm{L}^{-1}\right)$ : Yeast extract 5; Peptone 5; $\mathrm{NaCl} 5$; soluble starch 2; Agar 20; PG media (g $\left.\cdot \mathrm{L}^{-1}\right)$ : Peptone 5; Gelatin 4; Yeast extract 3; Agar 20; CMC media $\left(\mathrm{g} \cdot \mathrm{L}^{-1}\right)$ : Carboxymethylcellulose 5 ; Yeast extract 5 ; Peptone 5; $\mathrm{NaCl} 5$; Agar 20; TB media $\left(\mathrm{g} \cdot \mathrm{L}^{-1}\right)$ : Tributyrin agar base $23.00 \mathrm{~g}$ in $990 \mathrm{~mL}$ distilled water; Tributyrin 10 $\mathrm{mL}$; $\mathrm{XY}$ media $\left(\mathrm{g} \cdot \mathrm{L}^{-1}\right)$ : Peptone 5; Yeast extract 2; Mg$\mathrm{SO}_{4} \cdot 7 \mathrm{H}_{2} \mathrm{O} 0.5 ; \mathrm{NaCl} 0.5 ; \mathrm{CaCl}_{2} 0.15$; Birchwood xylan 20 ; Agar 20; MPS media $\left(\mathrm{g} \cdot \mathrm{L}^{-1}\right)$ : Glucose $10 ;\left(\mathrm{NH}_{4}\right)_{2} \mathrm{SO}_{4} 1.0$; Urea 10; Citric acid 3.0; Sodium citrate 2.0; $\mathrm{MgSO}_{4} .7 \mathrm{H}_{2} \mathrm{O}$ 1.0; Sodium phytate 3.0; $\mathrm{FeSO}_{4} .7 \mathrm{H}_{2} \mathrm{O}$ 0.01; Agar 20.

Pathogenic Aeromonas strains and maintenance of culture. Aeromonas salmonicida MTCC-1945 (AS) and Aeromonas hydrophila MTCC-1739 (AH) were acquired from the Microbial Type Culture Collection, Chandigarh, India. Aeromonas veronii KT737240 (AV) was isolated from diseased fish and established as pathogen for Catla catla in a previous study (Mukherjee and Ghosh 2014). The pathogenic strains were maintained on TSA (HiMedia) slants at $4^{\circ} \mathrm{C}$. Stock cultures raised in tryptone soya broth (TSB) were stored at $-70^{\circ} \mathrm{C}$ in $0.9 \% \mathrm{NaCl}$ with $20 \%$ glycerol to give constant inoculums during the study (Sugita et al. 1998).

Determination of extracellular enzyme production: qualitative and quantitative assay. Gut isolates were primarily evaluated for qualitative determination of extracellular enzyme-producing capacities following growth on the selective media plates containing respective sub- 
strates. Amylase and protease-producing capacities were determined on ST and PG plates through the development of clear halo zone when flooded with $1 \%$ Lugol's iodine or $15 \% \mathrm{HgCl}_{2}$, respectively (Jacob and Gerstein 1960). Cellulase production was determined on CMC plates flooded with Congo red prepared with $0.7 \%$ agarose (Teather and Wood 1982). Appearance of halo due to the presence of hydrolysed CMC indicated cellulase production in the medium. Lipase producing isolates showed halo surrounding their colony in TB plates containing 1\% tributyrin (Sangiliyandi and Gunasekaran 1996). Positive xylanolytic isolates were detected after flooding the XY plates with $0.5 \%(\mathrm{w} / \mathrm{v})$ Congo red and $5 \%$ ethanol followed by repeated washing with $1 \mathrm{M} \mathrm{NaCl}$ (Ninawe et al. 2006). Clear zone around the colonies on MPS media plates indicated phytase activity of the isolates (Howson and Davis 1983). Qualitative extracellular enzyme activity observed by the appearance of halo (diameter in $\mathrm{mm}$ ) around the colony was presented as scores (Das et al. 2014) as follows; 0, nil (no halo); 1, low (6-10 mm halo); 2, moderate (11-20 mm halo); 3 , good (21-30 mm halo); 4, high (31-39 $\mathrm{mm}$ halo); 5 , very high ( $\geq 40 \mathrm{~mm}$ halo).

On the basis of the cumulative scores, efficient extracellular enzyme producing isolates were selected for quantitative assay. Respective selective broth media were used as production media for the enzymes, viz., amylase, protease, cellulase, lipase, xylanase, and phytase. Quantitative assay for the production of amylase, cellulase, protease, and lipase were performed following the methods described by Bernfeld (1955), Denison and Koehn (1977), Walter (1984), and Bier (1955), respectively. A comprehensive description for measurement of these extracellular enzymes and quantitative enzyme assay has been mentioned elsewhere (Bairagi et al. 2002). Quantitative assay of xylanase and phytase activities were measured after Bailey et al. (1992) and Yanke et al. (1999), respectively. Enzyme activities were expressed as units (U).

Assay for pathogen inhibitory activity. Pathogen inhibitory activity of the promising enzyme-producing isolates were primarily tested by 'co-culture' (cross streaking) method (Alippi and Reynaldi 2006) and the strains that showed antagonism against $\geq 1$ studied Aeromonas spp. were further evaluated by the 'double-layer' method (Dopazo et al. 1988) with minor modification. Briefly, putative antagonistic strains grown on TSA plates were killed with chloroform vapour (15 $\mathrm{min})$, overlaid with the cultures containing the pathogenic strains and further incubated $\left(48 \mathrm{~h}\right.$ at $\left.30^{\circ} \mathrm{C}\right)$ for the development of inhibition zone (halo). Antibacterial activity indicated by the halo (diameter in $\mathrm{mm}$ ) around the colony was presented as follows; +, low (6-10 mm); ++, moderate (11-20 mm); +++, high $(21-25 \mathrm{~mm}) ;++++$, very high $(\geq 26 \mathrm{~mm})$. There were three replicates for each experimental set.

Growth on fish mucus. Mucus from fish skin (Ross et al. 2000) and intestine were collected from live Catla catla (mean length $17.6 \pm 2.16 \mathrm{~cm}$; mean weight $65.28 \pm 3.69 \mathrm{~g}$ ) and thereafter processed following Mukherjee and Ghosh (2014). Protein concentration of the mucus preparations were determined after Lowry et al. (1951) and adjusted to a concentration of $1 \mathrm{mg} \cdot \mathrm{mL}^{-1}$ for use as growth media. Samples were then filter-sterilized through 0.8 and 0.22 $\mu \mathrm{m}$ pore size filter paper (HiMedia) and stored at $-80^{\circ} \mathrm{C}$ until use. Filter sterilized mucus samples were separately inoculated $\left(10^{7} \mathrm{CFU} \cdot \mathrm{mL}^{-1}\right)$ with the two putative probiotics strains and grown at $30^{\circ} \mathrm{C}$ for $24 \mathrm{~h}$. To calculate the number of viable bacterial cells in mucus, serial dilutions $\left(10^{-3}, 10^{-4}\right.$, and $\left.10^{-5}\right)$ were made from $24 \mathrm{~h}, 48 \mathrm{~h}$, and $72 \mathrm{~h}$ cultures, inoculated $(0.1 \mathrm{~mL})$ onto TSA plates, incubated at $30^{\circ} \mathrm{C}$ for $24 \mathrm{~h}$ and colony-forming units $\left(\mathrm{CFU} \cdot \mathrm{mL}^{-1}\right)$ were counted. Plates inoculated with sterilized mucus were served as controls.

Bile tolerance. Crude bile juice ( $\mathrm{pH}$ 5.6) was collected from dissected gall bladders of the fish used for mucus collection, filter sterilized through $0.8 \mu \mathrm{m}$ and $0.22 \mu \mathrm{m}$ pore size filter papers (HiMedia, Mumbai, India) and stored at $-20^{\circ} \mathrm{C}$ until use. Bacteria grown in $\mathrm{TSB}\left(30^{\circ} \mathrm{C}\right.$, $24 \mathrm{~h})$ were centrifuged at $10000 \mathrm{~g}\left(10 \mathrm{~min}, 4^{\circ} \mathrm{C}\right)$ and bacterial suspensions were prepared in PBS. Sterile PBS (control) or sterile PBS supplemented with $2 \%-12 \%$ (v/v) fish bile juice was inoculated $\left(10^{7} \mathrm{CFU} \cdot \mathrm{mL}^{-1}\right)$ with the bacterial suspension as illustrated elsewhere (Nikoskelainen et al. 2001, Balcázar et al. 2008, Mukherjee and Ghosh 2014). Following incubation (1.5 h, $30^{\circ} \mathrm{C}$ ), the bacteria samples were serially diluted in sterile PBS and viable bacteria counts were determined on TSA media plates.

Intra-peritoneal injection test. Evaluation of bio-safety of the two putative probionts was performed by in vivo studies. A total of 45 healthy Catla catla fingerlings (15 \pm $1.31 \mathrm{~g}$ ) was maintained in $75 \mathrm{~L}$ glass aquaria and acclimatized in the laboratory condition for 2 weeks. Post acclimatization, the fingerlings were divided into three equal groups (two experimental and one control), each with three replicates ( 5 fish $\times 3$ groups $\times 3$ replicates). Overnight cultures of candidate probionts were centrifuged $\left(2800 \mathrm{~g}, 15 \mathrm{~min}, 4^{\circ} \mathrm{C}\right)$ and cell pellets were suspended in sterile $0.9 \%$ saline. All fish from each experimental group received intra-peritoneal (IP) injection of $1.0 \mathrm{~mL}$ containing $10^{9}$ cells $\cdot \mathrm{mL}^{-1}$ of a candidate probiotic bacterium. The fish in control group were injected with sterile $0.9 \%$ saline (Mesalhy et al. 2008). Fish were fed ad libitum with a diet containing approximately $35 \%$ crude protein having fishmeal as the major protein source. The fish were cultured for 21 days and observed daily for likely development of any disease symptom.

Co-culture test. The two putative probiotic strains were co-cultured with the previously isolated eight autochthonous fish gut bacteria, e.g., Bacillus licheniformis (KP940379), Bacillus subtilis subsp. spizizenii (KP940380), Bacillus aerophilus (KP940381), Bacillus cereus (KP940382), Bacillus safensis (HP940383), Bacillus methylotrophicus (KF559344), Bacillus subtilis subsp. spizizenii (KF559346), and Enterobacter hormaechei (KF559347) by 'cross-streaking' method. Disappearance of the gap on the culture plates indicated compatibility of the putative probionts with the other autochthonous bacterial strains. 
Morphological, physiological, and biochemical char-

acterization. Colony morphology was studied visually. Gram-staining procedure was performed for the determination of staining property. Endospore forming capacity was determined by staining with $5 \%$ aqueous malachite green. Culture characteristics were observed in broth and motility was studied using semi-solid media. Bacterial growth was observed at different temperatures $\left(4-50^{\circ} \mathrm{C}\right)$, $\mathrm{pH}(5.0-10.0)$, and under anaerobic conditions to see whether the bacteria can grow under anaerobic condition as well. Sodium chloride tolerance was determined by using different concentrations of $\mathrm{NaCl}(5 \%-15 \%$, $\mathrm{w} / \mathrm{v})$. In addition, pure cultures of the bacterial strains were subjected to various biochemical tests comprising of acid production from carbohydrates, arginine decarboxylation, arginine dihydrolation, urease, and citrate utilization.

Identification of the isolates by $16 \mathrm{~S}$ rRNA gene sequence analysis. The most promising two putative probiotics were studied through 16S rRNA partial gene sequence analysis after isolation and PCR amplification following the methods described in Das et al. (2014). The gene encoding 16S rRNA was amplified from the isolates by polymerase chain reaction (PCR) using universal primers (27f, 5' -AGAGTTTGATCCTGGCTCAG-3' and 1492r, 5'-GGTTACCTTGTTACGACTT-3'). The PCR reactions were performed using $20 \mu \mathrm{L}$ of PCR mix and $1 \mu \mathrm{L}$ of template DNA. To extract genomic DNA for obtaining template DNA from it, colonies were suspended in sterilized saline, centrifuged and the pellet suspended in InstaGene Matrix (Bio-Rad, USA). The cycle used for PCR reaction was: 35 cycles of denaturation at $94^{\circ} \mathrm{C}$ for $45 \mathrm{~s}$, annealing at $55^{\circ} \mathrm{C}$ for $1 \mathrm{~min}$, extension at $72^{\circ} \mathrm{C}$ for $1 \mathrm{~min}$ (Lane 1991). PCR products were purified by using Montage PCR Clean up kit (Millipore, USA). Sequencing of the purified PCR products were performed by using Big Dye terminator cycle sequencing kit (Applied BioSystems, USA). Sequencing products were resolved on an automated DNA sequencing system (Applied BioSystems 3730XL, USA). Sequenced data were edited using BioEdit Sequence Alignment Editor (Version 7.2.0), aligned and analysed for finding the closest homolog using National Centre for Biotechnology Information (NCBI) GenBank and Ribosomal Database Project (RDP) databases. Sequences were deposited to the NCBI GenBank and accession numbers were obtained. Phylogenetic tree was constructed incorporating 16S rRNA partial gene sequences of the closest type strains using MEGA 5.1Beta4 software following the Minimum Evolution Method.

Statistical analyses. Statistical analysis of the quantitative enzyme activity data was performed by the one-way analysis of variance (ANOVA), followed by Tukey's test according to Zar (1999) using SPSS Version 10 software (Kinnear and Gray 2000).

Ethical issues. Experimental fish were collected and handled following the approved guidelines of the Institutional Ethical Committee. As fish produced in aquaculture farm was used for the study, official permit was not required.

\section{RESULTS}

Isolation of gut bacteria and determination of extracellular enzyme-producing capacity. Diverse extracellular enzymes (viz. amylase, protease, cellulase, phytase, and xylanase) producing bacteria were represented in both, proximal (PI) and distal (DI) segments of the GI tract of Catla catla (Fig. 1). Heterotrophic and diverse extracellular enzyme-producing bacterial populations were found to be predominantly high in the DI region. While considering different extracellular enzyme-producing bacteria on a comparative scale, occurrence of cellulolytic bacteria was found to be the highest $(\mathrm{LVC}=6.14)$ followed by lipolytic bacteria ( $\mathrm{LVC}=5.77)$, both in distal intestine. Whereas, xylan-degrading population in the proximal intestine was noticed to be the lowest $(\mathrm{LVC}=3.48)$.

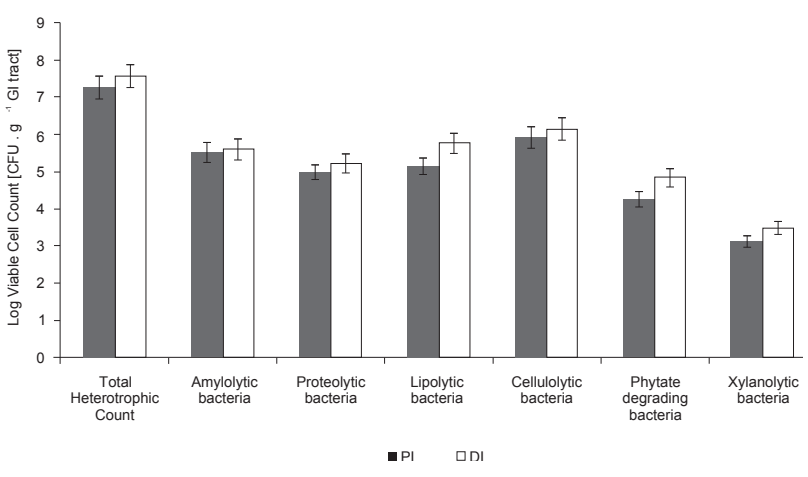

Fig. 1. Log viable counts of adherent bacteria isolated from the proximal intestine (PI) and distal intestine (DI) of Catla catla

Altogether 118 bacteria were isolated, out of which 17 extracellular enzyme producing strains (6 from PI and 11 from DI) were primarily selected on account of qualitative enzyme activity data presented as scores (Table 1), maximum and minimum scores being 29 and 15, respectively. Further, results of the quantitative enzyme assay revealed significant differences in the enzyme activities among the primarily selected bacterial isolates (Table 2). The highest amylolytic activity was noticed with the isolate $\mathrm{CCH} 1 \mathrm{~A}(349.37 \pm 6.05 \mathrm{U})$, while it was lowest in the isolate CCH3X $(125.44 \pm 3.83 \mathrm{U})$. The strain CCH1A exhibited maximum protease activity $(80.40 \pm 2.26 \mathrm{U})$ and minimum protease activity was evidenced with the strain CC2F3L $(21.75 \pm 1.07 \mathrm{U})$. All these strains were isolated from the DI regions. Maximum lipase activity was recorded with the strain CCH1A $(5.28 \pm 0.26 \mathrm{U})$ isolated from the DI region, being minimum with the strain $\mathrm{CC} 2 \mathrm{~F} 1 \mathrm{Ph}(4.11 \pm$ $0.19 \mathrm{U}$ ) isolated from the PI region. Maximum cellulase activity was documented with the strain CCF2P (73.51 \pm 2.19 $\mathrm{U})$ isolated from the PI region, while $\mathrm{CC} 2 \mathrm{H} 2 \mathrm{Ph}$, isolated from the DI region, exhibited minimum cellulase activity $(59.59 \pm 2.14 \mathrm{U})$. Maximum phytase activity was documented with the strain CCH1A $(396.45 \pm 6.31 \mathrm{U})$ isolated from the DI region, while $\mathrm{CC} 2 \mathrm{H} 2 \mathrm{Ph}$ isolated from the DI region, exhibited minimum phytase activity $(66.27 \pm 2.18$ $\mathrm{U})$. Maximum xylanase activity was documented with the strain $\mathrm{CCH} 1 \mathrm{Ph}(13.33 \pm 0.96 \mathrm{U})$ isolated from the DI re- 
gion, while CCF2P, isolated from the DI region, exhibited activity score being 28 and 29, respectively) were the most minimum xylanase activity $(6.54 \pm 0.22 \mathrm{U})$. Overall exam- efficient among the 30 primarily selected bacterial strains. ination of the six different extracellular enzyme activities Determination of antagonistic activity against revealed that the strains $\mathrm{CCH} 1 \mathrm{~A}$ and $\mathrm{CCH} 1 \mathrm{Ph}$ (qualitative Aeromonas spp. Further study concerning antagonism

Table 1

Qualitative determination of extracellular enzyme activity by the bacteria isolated from the gut of Catla catla

\begin{tabular}{|c|c|c|c|c|c|c|c|c|}
\hline \multirow{8}{*}{ 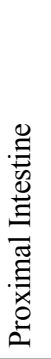 } & \multirow{2}{*}{ Strain } & \multicolumn{7}{|c|}{ Enzyme activity } \\
\hline & & Amylase $^{1}$ & Protease $^{2}$ & Lipase $^{3}$ & Cellulase $^{4}$ & Phytase $^{5}$ & Xylanase $^{6}$ & Total score \\
\hline & $\overline{C C F 3 L}$ & 4 & 5 & 4 & 5 & 2 & 2 & 22 \\
\hline & CCF2P & 4 & 5 & 4 & 5 & 2 & 2 & 22 \\
\hline & $\mathrm{CC} 2 \mathrm{~F} 1 \mathrm{Ph}$ & 3 & 3 & 2 & 3 & 3 & 3 & 17 \\
\hline & CC2F1A & 2 & 4 & 3 & 3 & 3 & 3 & 18 \\
\hline & $\mathrm{CC} 2 \mathrm{~F} 3 \mathrm{~L}$ & 5 & 1 & 4 & 3 & 0 & 2 & 15 \\
\hline & CC3F4A & 2 & 2 & 2 & 4 & 3 & 2 & 15 \\
\hline \multirow{11}{*}{ 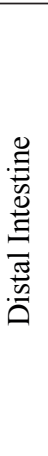 } & CCH1X & 3 & 2 & 3 & 5 & 0 & 3 & 16 \\
\hline & $\mathrm{CCH} 3 \mathrm{X}$ & 2 & 3 & 3 & 5 & 0 & 2 & 15 \\
\hline & CCH4X & 4 & 5 & 4 & 5 & 2 & 3 & 23 \\
\hline & CCH1A & 5 & 5 & 5 & 4 & 5 & 4 & 28 \\
\hline & $\mathrm{CCH} 3 \mathrm{~A}$ & 4 & 5 & 4 & 4 & 4 & 2 & 23 \\
\hline & CCH3L & 4 & 4 & 4 & 4 & 3 & 2 & 21 \\
\hline & $\mathrm{CCH} 3 \mathrm{C}$ & 3 & 5 & 4 & 4 & 2 & 2 & 20 \\
\hline & $\mathrm{CCH} 4 \mathrm{C}$ & 2 & 4 & 3 & 4 & 0 & 2 & 15 \\
\hline & $\mathrm{CCH} 1 \mathrm{Ph}$ & 5 & 5 & 5 & 5 & 5 & 4 & 29 \\
\hline & $\mathrm{CC} 2 \mathrm{H} 2 \mathrm{Ph}$ & 2 & 3 & 3 & 3 & 1 & 3 & 15 \\
\hline & CC2H8L & 3 & 4 & 3 & 4 & 2 & 3 & 19 \\
\hline
\end{tabular}

Enzyme activities (with pure culture of bacterial isolates) were presented as scores as described in the text; ${ }^{1}$ on starch (SA) plate; ${ }^{2}$ on gelatinpeptone (GP) plate; ${ }^{3}$ on Tributyrin-agar (TA) plate; ${ }^{4}$ on carboxymethylcellulose (CMC) plate; ${ }^{5}$ on modified phytase screen media (MPSM) plate; ${ }^{6}$ on birchwood xylan plate; Scores: $0=$ nil (no halo), $1=$ low $(6-10 \mathrm{~mm}$ halo diameter), $2=$ moderate $(11-20 \mathrm{~mm}$ halo diameter), $3=$ good (21-30 $\mathrm{mm}$ halo diameter), $4=$ high (31-39 $\mathrm{mm}$ halo diameter), $5=$ very high ( $\geq 40 \mathrm{~mm}$ halo diameter).

Table 2

Quantitative determination of extracellular enzyme activity (unit activity, U) by the bacteria isolated from the gut of Catla catla

\begin{tabular}{|c|c|c|c|c|c|c|c|}
\hline & \multirow{2}{*}{ Strain } & \multicolumn{6}{|c|}{ Enzyme activity [U] } \\
\hline & & Amylase $^{1}$ & Protease $^{2}$ & Lipase $^{3}$ & Cellulase $^{4}$ & Phytase $^{5}$ & Xylanase $^{6}$ \\
\hline \multirow{6}{*}{ 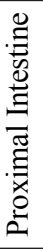 } & CCF3L & $241.13 \pm 5.28^{\mathrm{d}}$ & $73.54 \pm 2.28^{\mathrm{de}}$ & $4.36 \pm 0.17^{\mathrm{ab}}$ & $72.57 \pm 2.19^{c}$ & $80.50 \pm 2.29^{\mathrm{bc}}$ & $7.58 \pm 0.34^{b}$ \\
\hline & CCF2P & $250.44 \pm 5.87^{d}$ & $74.58 \pm 2.34^{\mathrm{de}}$ & $4.47 \pm 0.27^{\mathrm{ab}}$ & $73.51 \pm 2.19^{c}$ & $84.54 \pm 2.19^{\mathrm{bc}}$ & $6.54 \pm 0.22^{\mathrm{a}}$ \\
\hline & $\mathrm{CC} 2 \mathrm{~F} 1 \mathrm{Ph}$ & $191.80 \pm 4.28^{\mathrm{c}}$ & $55.34 \pm 2.44^{\mathrm{c}}$ & $4.11 \pm 0.19^{\mathrm{a}}$ & $62.48 \pm 2.30^{\mathrm{a}}$ & $198.71 \pm 4.84^{\mathrm{e}}$ & $7.33 \pm 0.24^{b}$ \\
\hline & CC2F1A & $129.53 \pm 3.83^{\mathrm{a}}$ & $70.61 \pm 2.29^{d}$ & $4.26 \pm 0.18^{\mathrm{ab}}$ & $59.67 \pm 2.38^{\mathrm{a}}$ & $191.23 \pm 4.70^{\mathrm{de}}$ & $7.27 \pm 0.39^{b}$ \\
\hline & $\mathrm{CC} 2 \mathrm{~F} 3 \mathrm{~L}$ & $275.48 \pm 5.92^{\mathrm{e}}$ & $21.75 \pm 1.07^{\mathrm{a}}$ & $4.59 \pm 0.13^{b}$ & $61.58 \pm 2.11^{\mathrm{a}}$ & - & $7.27 \pm 0.34^{b}$ \\
\hline & CC3F4A & $130.37 \pm 3.82^{\mathrm{a}}$ & $31.36 \pm 1.05^{\mathrm{b}}$ & $4.18 \pm 0.11^{\mathrm{a}}$ & $69.46 \pm 2.14^{\mathrm{bc}}$ & $186.66 \pm 4.68^{\mathrm{d}}$ & $7.14 \pm 0.32^{b}$ \\
\hline \multirow{11}{*}{ 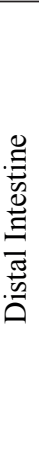 } & CCH1X & $167.19 \pm 4.87^{b}$ & $31.53 \pm 1.14^{\mathrm{b}}$ & $4.27 \pm 0.15^{\mathrm{a}}$ & $71.34 \pm 2.27^{\mathrm{bc}}$ & - & $7.39 \pm 0.28^{b}$ \\
\hline & $\mathrm{CCH} 3 \mathrm{X}$ & $125.44 \pm 3.83^{\mathrm{a}}$ & $52.58 \pm 2.19^{c}$ & $4.29 \pm 0.21^{\mathrm{ab}}$ & $72.30 \pm 2.36^{\mathrm{c}}$ & - & $7.02 \pm 0.24^{b}$ \\
\hline & $\mathrm{CCH} 4 \mathrm{X}$ & $239.45 \pm 5.81^{\mathrm{d}}$ & $73.58 \pm 2.12^{\mathrm{de}}$ & $4.51 \pm 0.24^{\mathrm{ab}}$ & $71.57 \pm 2.13^{\mathrm{bc}}$ & $86.48 \pm 2.22^{\mathrm{c}}$ & $7.20 \pm 0.31^{\mathrm{b}}$ \\
\hline & CCH1A & $349.37 \pm 6.05^{\mathrm{f}}$ & $80.40 \pm 2.26^{\mathrm{f}}$ & $5.28 \pm 0.26^{\mathrm{c}}$ & $70.52 \pm 2.27^{\mathrm{bc}}$ & $396.45 \pm 6.31^{\mathrm{gh}}$ & $11.76 \pm 0.88^{c}$ \\
\hline & $\mathrm{CCH} 3 \mathrm{~A}$ & $247.51 \pm 5.03^{\mathrm{d}}$ & $74.33 \pm 2.40^{\mathrm{de}}$ & $4.56 \pm 0.14^{\mathrm{b}}$ & $67.37 \pm 2.19^{b}$ & $210.42 \pm 5.87^{\mathrm{f}}$ & $6.98 \pm 0.26^{\mathrm{ab}}$ \\
\hline & $\mathrm{CCH} 3 \mathrm{~L}$ & $244.23 \pm 5.99^{\mathrm{d}}$ & $73.66 \pm 2.37^{\mathrm{de}}$ & $4.48 \pm 0.20^{\mathrm{ab}}$ & $61.60 \pm 2.22^{\mathrm{a}}$ & $200.40 \pm 5.94^{\mathrm{ef}}$ & $7.46 \pm 0.38^{b}$ \\
\hline & $\mathrm{CCH} 3 \mathrm{C}$ & $171.39 \pm 4.82^{b}$ & $79.61 \pm 2.35^{\mathrm{f}}$ & $4.41 \pm 0.25^{\mathrm{ab}}$ & $68.53 \pm 2.29^{\mathrm{bc}}$ & $82.48 \pm 2.11^{\mathrm{bc}}$ & $7.01 \pm 0.29^{\mathrm{ab}}$ \\
\hline & $\mathrm{CCH} 4 \mathrm{C}$ & $133.70 \pm 3.73^{\mathrm{a}}$ & $71.65 \pm 2.23^{\mathrm{d}}$ & $4.30 \pm 0.27^{\mathrm{ab}}$ & $67.62 \pm 2.26^{\mathrm{b}}$ & - & $7.09 \pm 0.30^{\mathrm{ab}}$ \\
\hline & $\mathrm{CCH} 1 \mathrm{Ph}$ & $281.21 \pm 5.64^{\mathrm{e}}$ & $77.56 \pm 2.31^{\mathrm{e}}$ & $4.92 \pm 0.13^{\mathrm{c}}$ & $72.28 \pm 2.31^{\mathrm{c}}$ & $387.04 \pm 6.08^{\mathrm{g}}$ & $13.33 \pm 0.96^{\mathrm{c}}$ \\
\hline & $\mathrm{CC} 2 \mathrm{H} 2 \mathrm{Ph}$ & $127.47 \pm 3.81^{\mathrm{a}}$ & $54.45 \pm 2.52^{\mathrm{c}}$ & $4.24 \pm 0.28^{\mathrm{ab}}$ & $59.59 \pm 2.14^{\mathrm{a}}$ & $66.27 \pm 2.18^{\mathrm{a}}$ & $7.18 \pm 0.34^{b}$ \\
\hline & CC2H8L & $186.46 \pm 4.78^{c}$ & $71.56 \pm 2.21^{\mathrm{d}}$ & $4.29 \pm 0.18^{\mathrm{ab}}$ & $69.40 \pm 2.31^{\mathrm{bc}}$ & $82.69 \pm 2.22^{\mathrm{bc}}$ & $7.17 \pm 0.33^{b}$ \\
\hline
\end{tabular}

Values are shown as mean \pm standard deviation $(n=3)$; Values with the same superscripts in the same vertical column are not significantly different $(P<0.05) ;{ }^{1} \mu \mathrm{g}$ maltose liberated $\mathrm{mL}^{-1}$ of enzyme extract $\min ^{-1} ;{ }^{2} \mu \mathrm{g}$ tyrosine liberated $\mathrm{mL}^{-1}$ of enzyme extract $\min ^{-1} ;{ }^{3} \mu \mathrm{mole}$ free fatty acid liberated $\mathrm{mL}^{-1}$ of enzyme extract $\min ^{-1} ;{ }^{4} \mu$ g glucose liberated $\mathrm{mL}^{-1}$ of enzyme extract $\mathrm{min}^{-1} ;{ }^{5} \mu$ g inorganic phosphate liberated $\mathrm{mL}^{-1}$ of enzyme extract $\mathrm{min}^{-1} ;{ }^{6} \mathrm{mg}$ D-xylose liberated $\mathrm{mL}^{-1}$ of enzyme extract $\mathrm{min}^{-1}$. 
against $A$. hydrophila, A. salmonicida, and $A$. veronii revealed that out of the 30 primarily selected isolates, 4 strains (2 each from PI and DI regions) could inhibit at least one of the tested Aeromonas spp. through cross-streaking method. Pathogen inhibitory activity of these 4 isolates were also assessed by double layer method and the zone of inhibition (halo) produced by the gut isolates were depicted in Table 3. In consequence of the maximum extracellular enzyme-producing capacities, the strain $\mathrm{CCH} 1 \mathrm{Ph}$ was also noticed to be antagonistic against all 3 of the among tested fish pathogens, whereas the strain CCH1A was found to be antagonistic against $A$. hydrophila and $A$. salmonicida among the tested pathogens. Therefore, these promising strains (CCH1A and $\mathrm{CCH} 1 \mathrm{Ph}$ ) were analysed further for evaluation of the other probiotic properties.

Phenotypic characterization of the candidate probiotic bacteria. Phenotypic characterization of the strains revealed that both the strains were long, Gram-positive rods, catalase positive and capable of forming irregular white colonies. Both were capable of utilizing starch, gelatin, nitrate, and produced acid from arabinose, dextrose, mannitol, and xylose. In addition to these common characteristics, the strains differ in some others. $\mathrm{CCH} 1 \mathrm{~A}$ could grow at $8^{\circ} \mathrm{C}$ but could not tolerate higher temperatures, unlike $\mathrm{CCH} 1 \mathrm{Ph}$. It also gives negative results for arginine dihydrolase and urease test. On the other hand, $\mathrm{CCH} 1 \mathrm{Ph}$ showed better acid tolerance and can utilize a number of carbon sources like cellobiose, inositol, raffinose, and rhamnose. However, it could not utilize amino acids like alanine and tryptophan (Table 4).

Genotypic identification of the selected isolates. Based on the nucleotide homology and phylogenetic analysis of the 16S rRNA partial gene sequences by nucleotide blast in the NCBI GenBank and RDP databases, the putative probiotic strain CCH1A was identified as Bacillus aerius (GenBank Accession No. KF623288), which was closest to the type strain Bacillus aerius (AJ831843.1). The other isolate, $\mathrm{CCH} 1 \mathrm{Ph}$ was identified as Bacillus sonorensis (GenBank Accession No. KF623289) that showed maximum similarity with the type strain Bacillus sonorensis (AF302118.1). Phylogenetic relation of the two identified bacterial isolates with other closely related type strains retrieved from the RDP database were presented in the dendrogram (Fig. 2).

Evaluation of growth in skin and intestinal mucus. The strains, $\mathrm{CCH} 1 \mathrm{~A}$ and $\mathrm{CCH} 1 \mathrm{Ph}$, grew well in mucus of Catla catla (Fig. 3) collected from both skin and intestine. Log viable cell count $\left(\mathrm{CFU} \cdot \mathrm{mL}^{-1}\right)$ for both the candidate probionts indicated that the strains were more potent to grow in mucus collected from intestine than that of skin. Bile tolerance. Both the candidate probiotic bacteria, $\mathrm{CCH} 1 \mathrm{~A}$ and $\mathrm{CCH} 1 \mathrm{Ph}$, showed tolerance against diluted bile juice. The selected bacterial strains survived after $1.5 \mathrm{~h}$ exposure to different concentrations of bile juice $(0 \%-12 \%)$ ranging $\mathrm{pH}$ values $5.5-7$ (Table 5). Moreover, marked changes were not detected in the growth of the selected bacteria even after exposure to the diluted bile juice (12\%) for $24 \mathrm{~h}$ (data not presented).

Bio-safety of the candidate probiotic bacteria. Along with the control set, intra-peritoneal injection of the can-
Table 3

Inhibition zone produced by the bacteria isolated from the gut of Catla catla in double layer method

\begin{tabular}{lccc}
\hline \multirow{2}{*}{ Strain } & \multicolumn{3}{c}{ Score } \\
\cline { 2 - 4 } & AH & AS & AV \\
\hline CCF2P & ++++ & ++++ & + \\
CCH1Ph & ++++ & +++ & ++++ \\
CCH1A & ++++ & +++ & - \\
CC2F1A & + & - & - \\
\hline
\end{tabular}

$\mathrm{AH}=$ Aeromonas hydrophila, $\mathrm{AS}=$ Aeromonas salmonicida, $\mathrm{AV}$ = Aeromonas veronii ; Score: + low (6-10 mm halo diameter), ++ moderate (11-20mm halo diameter), +++ high (21-25 mm halo diameter), ++++ very high ( $\geq 26 \mathrm{~mm}$ halo diameter), - no antagonism.

Table 4

Key biochemical characteristics differentiating strains CCH1A (Bacillus aerius) and CCH1Ph (Bacillus sonorensis)

\begin{tabular}{|c|c|c|c|}
\hline \multicolumn{2}{|c|}{ Characteristics } & \multicolumn{2}{|c|}{$\mathrm{CCH} 1 \mathrm{~A} \mathrm{CCH} 1 \mathrm{Ph}$} \\
\hline & Arginine decarboxylase & + & - \\
\hline & Arginine dihydrolase & - & + \\
\hline & Citrate utilization & + & - \\
\hline & Urease & - & + \\
\hline Tolerance of $\mathrm{NaCl}$ & $11 \%$ & + & - \\
\hline \multirow[t]{4}{*}{ Growth at } & $8^{\circ} \mathrm{C}$ & + & - \\
\hline & $40^{\circ} \mathrm{C}$ & - & + \\
\hline & $45^{\circ} \mathrm{C}$ & - & + \\
\hline & pH 5.5 & - & + \\
\hline \multirow[t]{12}{*}{ Carbon source utilization } & $N$-Acetylglucosamine & - & + \\
\hline & D-Cellobiose & - & + \\
\hline & Citric acid & + & - \\
\hline & Dulcitol & - & + \\
\hline & myo-Inositol & - & + \\
\hline & D-Raffinose & - & + \\
\hline & D-Rhamnose & - & + \\
\hline & Sodium succinate & + & - \\
\hline & L-Sorbose & + & - \\
\hline & Thioglycolate & + & - \\
\hline & Xylitol & + & - \\
\hline & $\begin{array}{l}\text { Acid from } \\
\text { D-Maltose }\end{array}$ & + & - \\
\hline \multirow[t]{3}{*}{ Amino acid utilization } & L-Alanine & + & - \\
\hline & L-Threonine & - & + \\
\hline & L-Tryptophan & + & - \\
\hline
\end{tabular}

+ Positive, - Negative.

didate probiotics did not induce any pathological signs/ disease symptoms or mortalities in both treatment groups during the 21 days small-scale in vivo experiment. Test of co-culture (in vitro) against eight autochthonous fish gut bacteria revealed that the selected bacterial strains did not hinder growth of the normal gut flora. Therefore, the selected putative probionts were compatible with the other commonly occurring autochthonous fish gut bacteria. 


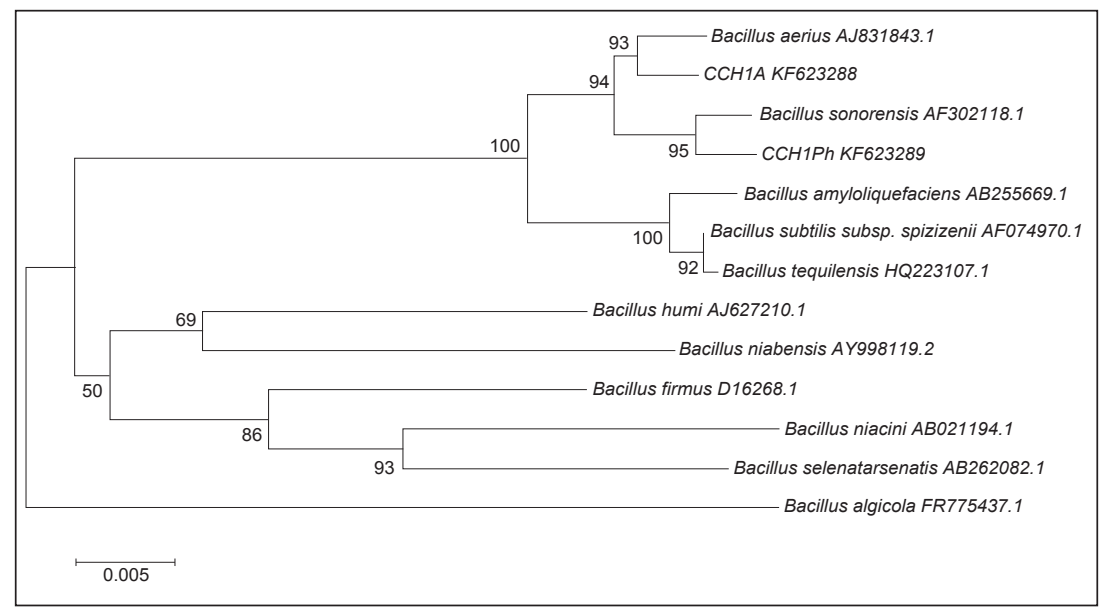

Fig. 2. Dendrogram showing phylogenetic relations of the two potential probiotic bacterial strains, Bacillus aerius CCH1A (KF623288) and Bacillus sonorensis CCHIPh (KF623289), isolated from Catla catla, with other closely related strains retrieved from NCBI GenBank and RDP; The GenBank accession numbers of the reference strains are shown besides the names; Horizontal bars in the dendrogram represent the branch length; Similarity and homology of the neighbouring sequences have been shown by bootstrap values; Distance matrix was calculated by Tamura 3+Gamma model; The scale bar indicates 0.005 substitutions per nucleotide position; Bacillus algicola FR775437.1 served as an outgroup

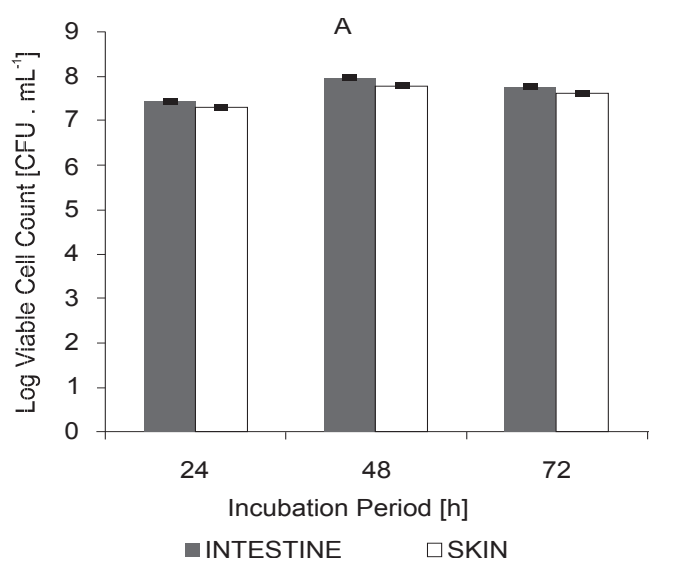

Tolerance of the selected isolates at different concentrations of fish bile juice for $1.5 \mathrm{~h}$ at $30^{\circ} \mathrm{C}$

\begin{tabular}{ccc}
\hline \multirow{2}{*}{ Bile [\%] } & \multicolumn{2}{c}{ Log CFU· $\mathrm{mL}^{-1}$} \\
\cline { 2 - 3 } & CCH1A & CCH1Ph \\
\hline 0 & $6.91 \pm 0.007$ & $6.93 \pm 0.008$ \\
1 & $6.91 \pm 0.006$ & $6.93 \pm 0.009$ \\
2 & $6.88 \pm 0.004$ & $6.92 \pm 0.007$ \\
3 & $6.88 \pm 0.004$ & $6.92 \pm 0.008$ \\
4 & $6.87 \pm 0.004$ & $6.90 \pm 0.007$ \\
5 & $6.86 \pm 0.006$ & $6.90 \pm 0.005$ \\
6 & $6.86 \pm 0.003$ & $6.88 \pm 0.005$ \\
7 & $6.86 \pm 0.005$ & $6.88 \pm 0.003$ \\
8 & $6.84 \pm 0.005$ & $6.87 \pm 0.006$ \\
9 & $6.84 \pm 0.007$ & $6.86 \pm 0.002$ \\
10 & $6.83 \pm 0.001$ & $6.86 \pm 0.004$ \\
11 & $6.81 \pm 0.001$ & $6.83 \pm 0.003$ \\
12 & $6.80 \pm 0.003$ & $6.81 \pm 0.004$ \\
\hline
\end{tabular}

Viable count was determined on TSA plates inoculated with bile exposed bacterial suspension; Values are shown as mean \pm standard deviation $(n=3)$

\section{DISCUSSION}

The primary step for acquisition of potential probionts to be used in an aquaculture system is the collection of background information on the prospective microorganisms and their hosts (Gomez-Gil et al. 2000). The presently reported study evaluated population of heterotrophic as

Fig. 3. Log values of viable count of the selected gut bacteria isolated from Catla catla: CCH1A (Bacillus aerius) (A) and CCHIPh (Bacillus sonorensis) (B) grown in skin and intestinal mucus of Catla catla; Viable count was done on TSA plates inoculated with respective bacteria cultures of $24 \mathrm{~h}, 48 \mathrm{~h}$, and $72 \mathrm{~h}$ in fish mucus well as different extracellular enzyme-producing bacteria in the PI and DI regions of the GI tract in Catla catla. Although, gut bacteria in catla were noticed to be dominated by the cellulolytic bacteria, existence of lipolytic, amylolytic, and proteolytic bacteria clearly advocated omnivorous feeding aptitude of the species as suggested elsewhere (Dasgupta 1996, Ghosh et al. 2002a, Khabade 
2015). Occurrence of higher numbers of heterotrophic enzyme-producing bacteria in DI region compared to the PI region was in agreement with the previous reports (Mondal et al. 2008, Das et al 2014). This might indicate the possibility of microbial degradation of the food material in this part of the GI tract in assistance with the highly colonized enzyme-producing bacteria (Ghosh et al. 2010). Therefore, evaluation of beneficial attributes of the gut bacteria with high enzyme-producing capacity to select putative probiotics for fish may be justified.

In search of the best suited bacterial probiotics for fish, isolation followed by a series of consecutive screening process have been suggested to cover both functional and safety aspects of the putative probiotics (Vine et al. 2006). Moreover, the presently reported study emphasized autochthonous gut microorganisms as the putative probiotics assuming that the resident flora would be well adapted within the gut micro-environment of the host fish (Dutta and Ghosh 2015). Previous investigations have suggested beneficial attributes of the gut bacteria in the digestive processes of fish (Austin 2006, Nayak 2010). Likely use of extracellular enzyme producing bacteria as probiotics have called attention to promote nutritional benefits in the Indian major carps and other cultivable fish (Ghosh et al. 2002a, 2002b, Askarian et al. 2012). Therefore, in view of inducing improved nutrient utilization in fish, exogenous enzyme producing ability was considered as the primary criteria for the candidate probionts. Results of the presently reported study depicted that heterotrophic community within the GI tract of $C$. catla were represented by amylase, protease, lipase (digestive enzymes), cellulase, phytase, and xylanase (anti-nutritional factor degrading enzymes) producing bacteria. The results pertaining quantitative assay of extracellular enzymes produced by diverse strains isolated in the presently reported study indicated that the capacity of extracellular enzyme production varied among the isolates (Table 2). Thus, the strains that exhibited a high capacity for secreting exoenzymes could be selected as putative probiotic candidates to facilitate feed utilization in the fish. A total of 118 extracellular enzyme producing isolates were obtained from the proximal and distal parts of the intestine. Scores were assigned to the strains based on the qualitative analysis of the extracellular enzyme activity and strains with individual score $\geq 15$ (17 strains out of 118) were considered as strong enzyme producers, which were further confirmed by the quantitative assay. This preliminary screening has resulted in an elimination of $85.6 \%(n=101)$ of the total isolates from current study. Diverse enzyme producing bacteria were recorded from the GI tracts of the Indian major carps in previous studies (for review see Ray et al. 2012). The majority of these studies addressed digestive (amylase, protease, lipase) and/or anti-nutritional factors (ANF) degrading enzymes (cellulase, phytase) producing capacity by the GI tract bacteria. However, the presently reported study represented a combined approach to consider the ability of both digestive as well as anti-nutritional factors degrading enzymes producing ability as the selection criteria of the putative probiotics.
The production of antimicrobial substances by some bacteria seemed to play an important role in antagonizing other bacteria in aquatic ecosystems (Dopazo et al. 1988). In view of this context, the use of non-pathogenic and antimicrobial-producing bacteria as probiotic bio-control agents might have a prospect in disease management. Therefore, pathogen inhibitory activity of the bacteria has been considered as the major criterion for the selection of probiotics in several studies (Vine et al. 2006). However, to the authors' knowledge, such information is scarce with respect to gut bacteria from IMCs with high enzymatic activities (Mukherjee and Ghosh 2014, Dutta and Ghosh 2015). Hence, demonstration of antagonistic properties against Aeromonas spp., the predominant fish pathogen in the tropical countries, was chosen as the second criterion for the selection of candidate probionts in the presently reported study. Among the promising enzyme producers, 4 strains were noticed to be antagonistic against at least one of the three fish pathogens tested. Although a different degree of pathogen inhibition was detected in this study, the inhibition zones exhibited by the strong antagonists (CCH1Ph, CCF2P, and CCH1A) through the double layer assay were similar to those reported by Ghosh et al. (2007) for B. subtilis SG4 and Krishnan (2014) for Bacillus sp. against different strains of $A$. hydrophila. The strongest inhibitory activity towards the Aeromonas spp. in terms of the zone of inhibition was displayed by the strain $\mathrm{CCH} 1 \mathrm{Ph}$. Our study revealed 4 out of 17 efficient extracellular enzyme-producing strains to be antagonistic (23.5\%) against Aeromonas spp. Previously, Sugita et al. (1996) documented $3.2 \%$ of the gastrointestinal bacterial isolates to be antagonistic against 18 different pathogens including 12 Aeromonas spp. Nonetheless, it could be hypothesized from the present investigation that the extracellular enzyme-producing bacteria colonizing within the GI tract of Catla catla might offer protection against the pathogenic Aeromonas strains. Although, the mechanism of inhibition was not characterized here, preceding studies suggested that the growth of pathogens (e.g., A. hydrophila) might be inhibited by competitive exclusion, competition for essential nutrients (e.g., glucose and iron) and siderophore production (Lalloo et al. 2010). The method used in the presently reported study to assay the antagonistic effect of the putative probiotics (agar-overlay/double-layer) demonstrates the influence of diffusing antimicrobial products on growth of the pathogenic bacteria. Thus, besides competitive exclusion, our results might indicate secretion of the antibacterial compounds by the strains $\mathrm{CCH} 1 \mathrm{~A}$ and $\mathrm{CCH} 1 \mathrm{Ph}$ inhibiting the growth of Aeromonas spp. as opined by Geraylou et al. (2014) and Mukherjee and Ghosh (2014).

Afterwards, considering extracellular enzyme producing capacity and antagonism against Aeromonas spp. together, two isolates ( $\mathrm{CCH} 1 \mathrm{~A}$ and $\mathrm{CCH} 1 \mathrm{Ph})$ categorized as putative probiotics were identified by molecular as well as conventional methods and further characterized for verification of other probiotic attributes. Analysis of the 16S rRNA partial gene sequences and nucleotide homology revealed that the strains $\mathrm{CCH} 1 \mathrm{~A}$ and $\mathrm{CCH} 1 \mathrm{Ph}$, were 
Bacillus aerius (GenBank Accession No. KF623288) and Bacillus sonorensis (GenBank Accession No. KF623289), respectively. Extracellular enzyme-producing ability of the diverse Bacillus spp. isolated from the GI tract of different freshwater fish species has been widely documented (for review see, Ray et al. 2012). In comparison, pathogen inhibitory potential of the bacilli has been rarely indicated. B. subtilis SG4 isolated from the gut of mrigal, C. mrigala (see Ghosh et al. 2007), B. methylotrophicus isolated from channel catfish intestine (Ran et al. 2012), and $B$. cereus and B. circulans isolated from the gut of some other fish species (Lalloo et al. 2010, Geraylou et al. 2014) were reported to be antagonistic against different strains of $A$. hydrophila. In addition, enzyme-producing $B$. thuringiensis isolated from the GI tract of the Atlantic salmon, Salmo salar Linnaeus, 1758, was shown to inhibit A. salmonicida subsp. salmonicida and 3 other pathogenic bacteria (Askarian et al. 2012). Extracellular digestive enzyme-producing B. subtilis BHI344 isolated from the GI tract of the channel catfish, Ictalurus punctatus (Rafinesque, 1818), was shown to inhibit (in vitro) the growth of pathogenic A. hydrophila, A. sobria, and A. caviae (see Luo et al. 2014). In the presently reported study, $B$. sonorensis $\mathrm{CCH} 1 \mathrm{Ph}$ exhibited inhibitory effects against $A$. hydrophila, $A$. veronii, and $A$. salmonicida. Unlike to the present observation, another isolate of $B$. sonorensis $\mathrm{CM} 2 \mathrm{H} 3 \mathrm{~L}$ from the gut of $C$. mrigala has been reported to inhibit only A. salmonicida, however, neither $A$. hydrophila nor $A$. veronii was inhibited (Dutta and Ghosh 2015). To the authors' knowledge, extracellular enzyme-producing ability and/or pathogen inhibitory potential of $B$. aerius from fish gut depicted in the present study has not been reported previously.

Apart from the functional attributes (e.g., enzyme secretion, pathogen inhibition etc.) a probiotic bacterium should have the capacity to withstand the fish GI tract conditions. Therefore, growth in fish mucus and tolerance to fish bile were considered as additional criteria to verify the probiotic features. Both of the selected gut bacteria grew well in fish mucus, although, minor differences were noted in bacterial growth rate which might be due to specific nutritional requirements of the bacteria (Geraylou et al. 2014). In accordance to the observation made by Mukherjee and Ghosh (2014), the presently reported study also revealed that intestinal mucus is a better growth medium for the selected putative probiotics than the skin mucus. Further, both $B$. aerius $\mathrm{CCH} 1 \mathrm{~A}$ and B. sonorensis $\mathrm{CCH} 1 \mathrm{Ph}$ were found to tolerate $9 \%$ and $10.5 \%$ of the diluted bile juice, respectively. The physiological concentration of bile was reported to be nearly $0.4 \%-1.3 \%$ within the fish GI tract (Balcázar et al. 2008). Thus, tolerance to the bile juice represented by the gut isolates in the present study was relatively high. Similar observations were recorded by several authors to establish bile tolerance of the putative probiotic bacteria against fish bile (Nikoskelainen et al. 2001, Burbank et al. 2012, Mukherjee and Ghosh 2014) or commercial bile salts (Allameh et al. 2014, Geraylou et al. 2014). Finally, bio-safety towards the host is an indispensable criterion for any of the probiotic bacteria under critical evaluation (Verschuere et al. 2000). Although, several Bacilli were demonstrated as probiotics for fish, some other strains of $B$. cereus or B. subtilis were established as fish pathogens (Pychyński et al. 1981). In the presently reported study, small scale in vivo study with the two selected putative probiotic strains did not induce any pathological signs or mortalities in Catla catla and therefore, considered as safe. The extent of the antagonism by the adherent gut bacteria might also represent possibility of negative interaction against the other resident flora. A co-culture test with the previously isolated autochthonous gut bacteria of catla revealed that the putative probiotic strains did not affect their growth. Therefore, likely co-existence of the diverse autochthonous bacteria and putative probiotics selected in the presently reported study could be substantiated within the fish species under observation.

\section{CONCLUSIONS AND PERSPECTIVES FOR THE FUTURE}

As evident from the observations made during the last few decades, gut microbiota within the freshwater fishes were somewhat dominated by the Bacillus spp. (Ghosh et al. 2010, Ray et al. 2010), which were in conformity with the present report. Further, Bacillus spp. seemed to be the most common probiotics as they can be stored easily in the spore form for an indefinite period (Hong et al. 2005), and therefore, convenient for easy preparation to add into the artificial diets (Bisht et al. 2012). With a combined approach of different screening strategies, the strains $B$. aerius $\mathrm{CCH} 1 \mathrm{~A}$ and $B$. sonorensis $\mathrm{CCH} 1 \mathrm{Ph}$ were selected as putative probiotics in the presently reported study. A combination of two screening strategies for selecting probiotics might be far superior to normally prevalent single screening strategy as they could mutually complement each other (Luo et al. 2014). While probiotic attributes of $B$. sonorensis from other fish species (C. mrigala) has been documented very recently (Dutta and Ghosh 2015), to the authors' knowledge, this is the first report pertaining likely probiotic potential of $B$. aerius isolated from the fish gut. Although, postulations based on in vitro experiments might not act in accordance with in vivo conditions, indigenous strains originating from the fish GI tract might ensure viability and colonization of the selected strains to confer a health benefit. However, long term in vivo studies are warranted with these autochthonous strains to determine their effects on growth and likely health benefits of Catla catla.

\section{ACKNOWLEDGEMENTS}

Sincere thanks to the Head, Department of Zoology, The University of Burdwan, West Bengal, India; The Department of Science and Technology (FIST programme), New Delhi, India and The University Grants Commission (UGC-SAP-DRS programme), New Delhi, India for providing research facilities. The first author is grateful to The Council of Scientific and Industrial Research, New Delhi, India for awarding the Junior Research Fellowship. 


\section{REFERENCES}

Akinbowale O.L., Peng H., Barton M.D. 2006. Antimicrobial resistance in bacteria isolated from aquaculture sources in Australia. Journal of Applied Microbiology 100 (5): 1103-1113.

DOI: $10.1111 / \mathrm{j} .1365-2672.2006 .02812 . x$

Alippi A.M., Reynaldi F.J. 2006. Inhibition of the growth of Paenibacillus larvae, the causal agent of American foulbrood of honeybees, by selected strains of aerobic spore-forming bacteria isolated from apiarian sources. Journal of Invertebrate Pathology 91 (3): 141-146. DOI: 10.1016/j.jip.2005.12.002

Allameh S.K., Ringø E., Yusoff F.M., Daud H.M., Ideris A. 2014. Properties of Enterococcus faecalis, a new probiotic bacterium isolated from the intestine of snakehead fish (Channa striatus Bloch). African Journal of Microbiology Research 8 (22): 2215-2222. DOI: 10.5897 /ajmr2013.5830

Askarian F., Zhou Z., Olsen R.E., Sperstad S., Ringo E. 2012. Culturable autochthonous bacteria in Atlantic salmon (Salmo salar L.) fed diets with or without chitin. Characterization by $16 \mathrm{~S}$ rRNA gene sequencing, ability to produce enzymes and in vitro growth inhibition of four fish pathogens. Aquaculture 326-329: 1-8. DOI: 10.1016/j.aquaculture.2011.10.016

Austin B. 2006. The bacterial microflora of fish, revised. The Scientific World Journal 6: 931-945.

DOI: $10.1100 /$ tsw.2006.181

Bailey M.J., Biely P., Poutanen K. 1992. Interlaboratory testing of method for assay of xylanase activity. Journal of Biotechnology 23 (3): 257-270. DOI: 10.1016/0168-1656(92)90074-j

Bairagi A., Sarkar Ghosh K., Sen S.K., Ray A.K. 2002. Enzyme producing bacterial flora isolated from fish digestive tracts. Aquaculture International 10 (2): 109-121.

DOI: $10.1023 / \mathrm{A}: 1021355406412$

Balcázar J.L., de Blas I., Ruiz-Zarzuela I., Cunningham D., Vendrell D., Muźquiz J.L. 2006. The role of probiotics in aquaculture. Veterinary Microbiology 114 (3-4): 173-186.

DOI: 10.1016/j.vetmic.2006.01.009

Balcázar J.L., Vendrell D., de Blas I., Ruiz-Zarzuela I., Muźquiz J.L., Girones O. 2008. Characterization of probiotic properties of lactic acid bacteria isolated from intestinal microbiota of fish. Aquaculture $\mathbf{2 7 8}$ (1-4): 188-191.

DOI: 10.1016/j.aquaculture.2008.03.014

Bernfeld P. 1955. [17] Amylases, $\alpha$ and $\beta$. DOI: 10.1016/0076-6879(55)01021-5. Pp. 149-158. In: Colowick S.P., Kaplan N.O. (eds.) Methods in enzymology. Vol. 1. Academic Press, New York NY, USA.

Beveridge M.C.M., Sikdar P.K., Frerichs G.N., Millar S. 1991. The ingestion of bacteria in suspension by the common carp Cyprinus carpio L. Journal of Fish Biology 39 (6): 825-831.

DOI: $10.1111 /$ j.1095-8649.1991.tb04412.x
Bier M. 1955. [106] Lipases: $\mathrm{RCOOR}^{\prime}+\mathrm{H}_{2} \mathrm{O} \rightarrow \mathrm{RCOOH}$ $+\mathrm{R}^{\prime} \mathrm{OH}$. Pp. 627-642.

DOI: 10.1016/0076-6879(55)01111-7. In: Colowick S.P., Kaplan N.O. (eds.) Methods in enzymology. Vol. 1. Academic Press, New York NY, USA.

Bisht A., Singh U.P., Pandey N.N. 2012. Bacillus subtilis as a potent probiotic for enhancing growth in fingerlings of common carp (Cyprinus carpio L.). Indian Journal of Fisheries 59 (3): 103-108.

Burbank D.R., LaPatra S.E., Fornshell G., Cain K.D. 2012. Isolation of bacterial probiotic candidates from the gastrointestinal tract of rainbow trout, Oncorhynchus mykiss (Walbaum), and screening for inhibitory activity against Flavobacterium psychrophilum. Journal of Fish Diseases 35 (11): 809-816.

DOI: $10.1111 /$ j.1365-2761.2012.01432.x

Das P., Mandal S., Khan A., Manna S.K., Ghosh K. 2014. Distribution of extracellular enzyme-producing bacteria in the digestive tracts of 4 brackish water fish species. Turkish Journal of Zoology 38 (1): 79-88. DOI: 10.3906/zoo-1205-3

Dasgupta M. 1996. Alimentary canal of Catla catla (Hamilton) in relation to its food and feeding habits. Indian Journal of Fisheries 43 (4): 385-387.

Denison D.A., Kohen R.D. 1977. Cellulase activity of Poronia oedipus. Mycologia 69 (3): 592-601. DOI: $10.2307 / 3758562$

Dopazo C., Lemos M., Lodeiros C., Bolinches J., Barja J., Toranzo A. 1988. Inhibitory activity of antibiotic-producing marine bacteria against fish pathogens. Journal of Applied Bacteriology 65 (2): 97-101. DOI: $10.1111 /$ j.1365-2672.1988.tb01497.x

Dutta D., Ghosh K. 2015. Screening of extracellular enzyme-producing and pathogen inhibitory gut bacteria as putative probiotics in mrigal, Cirrhinus mrigala (Hamilton, 1822). International Journal of Fisheries and Aquatic Studies 2 (4): 310-318.

Geraylou Z., Vanhove M.P.M., Souffreau C., Rurangwa E., Buyse J., Ollevier F. 2014. In vitro selection and characterization of putative probiotics isolated from the gut of Acipenser baerii (Brandt, 1869). Aquaculture Research 45 (2): 341-352. DOI: $10.1111 /$ j.1365-2109.2012.03232.x

Ghosh K., Roy M., Kar N., Ringø E. 2010. Gastrointestinal bacteria in rohu, Labeo rohita (Actinopterygii: Cypriniformes: Cyprinidae): Scanning electron microscopy and bacteriological study. Acta Ichthyologica et Piscatoria 40 (2): 129-135. DOI: 10.3750/aip2010.40.2.05

Ghosh K., Sen S.K., Ray A.K. 2002a. Characterization of bacilli isolated from gut of rohu, Labeo rohita, fingerlings and its significance in digestion. Journal of Applied Aquaculture 12 (3): 33-42. DOI: $10.1300 / j 028 v 12$ n03 04

Ghosh K., Sen S.K., Ray A.K. 2002b. Growth and survival of rohu, Labeo rohita (Hamilton) spawn fed diets supplemented with fish intestinal microflora. Acta Ichthyologica et Piscatoria 32 (1): 83-92. 
Ghosh S., Sinha A., Sahu C. 2007. Isolation of putative probionts from the intestines of Indian major carps. Israeli Journal of Aquaculture-Bamidgeh 59 (3): 127132.

Gomez-Gil B., Roque A., Turnbull J.F. 2000. The use and selection of probiotic bacteria for use in the culture of larval aquatic organisms. Aquaculture 191 (1-3): 259-270.

DOI: $10.1016 / \mathrm{s} 0044-8486(00) 00431-2$

Hong H.A., Duc L.H., Cutting S.M. 2005. The use of bacterial spore formers as probiotics. FEMS Microbiology Reviews 29 (4): 813-835.

DOI: $10.1016 /$ j.femsre.2004.12.001

Howson S.J., Davis R.P. 1983. Production of phytate hydrolyzing enzyme by some fungi. Enzyme and Microbial Technology 5 (5): 377-382.

DOI: 10.1016/0141-0229(83)90012-1

Jacob M.B., Gerstein M.J. 1960. Handbook of microbiology. D Van Nostrand Co Inc, Princeton, New Jersey.

Karunasagar I., Ali P.K.M.M., Jeyasekaran G., Karunasagar I. 1986. Ulcerative form of Aeromonas hydrophila infection of Catla catla. Current Science 55 (23): 1194-1195.

Kesarcodi-Watson A., Kaspar H., Lategan M.J., Gibson L. 2008. Probiotics in aquaculture: The need, principles and mechanisms of action and screening processes. Aquaculture 274 (1): 1-14.

DOI: $10.1016 /$ j.aquaculture.2007.11.019

Khabade S.A. 2015. Study of gut contents of major carps for their food habits from Sidddhewadi lake of Tasgaon tahsil of Sangli district Maharashtra. International Journal of Fisheries and Aquatic Studies 2 (4): 1-4.

Khatri S., Sahu J., Prasad M.M. 2009. Prevalence of fish diseases in Sambalpur, Orissa, India. Asian Fisheries Science 22 (2): 569-581.

Kinnear P.R., Gray C.D. 2000. SPSS for Windows made simple. Psychology Press, Sussex, UK.

Krishnan R. 2014. Probiotic potential of Bacillus species isolated from freshwater fish Anabas testudineus in Labeo rohita. International Journal of Multidisciplinary Research and Development 1 (1): 46-50.

Lalloo R., Moonsamy G., Ramchuran S., Görgens J., Gardiner N. 2010. Competitive exclusion as a mode of action of a novel Bacillus cereus aquaculture biological agent. Letters of Applied Microbiology 50 (6): 563-570.

DOI: $10.1111 /$ j.1472-765x.2010.02829.x

Lane D.J. 1991. 16S/23S rRNA sequencing. Pp. 115-175. In: Stackebrandt E., Goodfellow M. (eds.) Nucleic acid techniques in bacterial systematics. Wiley, New York NY, USA.

Lio-Po G.D., Lim L.H. S. 2014. Infectious diseases of warmwater fish in fresh water. Pp. 193-253. In: Woo P.T.K., Bruno D.W. (eds.) Diseases and disorders of finfish in cage culture. CAB International, Oxfordshire, UK.

Lowry O.H., Rosebrough N.J., Farr A.L., Randall R.J. 1951. Protein measurement with folin phenol reagent. Journal of Biological Chemistry 193 (1): 265-275.
Luo Z., Bai X.H., Chen C.F. 2014. Integrated application of two different screening strategies to select potential probiotics from the gut of channel catfish Ictalurus punctatus. Fisheries Science 80 (6): 1269-1275.

DOI: $10.1007 / \mathrm{s} 12562-014-0794-y$

Mandal S., Ghosh K. 2013. Isolation of tannase-producing microbiota from the gastrointestinal tracts of some freshwater fish. Journal of Applied Ichthyology 29 (1): 145-153.

DOI: $10.1111 /$ j.1439-0426.2012.02054.x

Marlida R., Suprayudi M.A., Widanarni, Harris E. 2014. Isolation, selection and application of probiotic bacteria for improvement the growth performance of humpback groupers (Cromileptes altivelis). International Journal of Sciences: Basic and Applied Research 16 (1): 364-369.

Mesalhy A.S., Abd-El-Rahman A.M., John G., Mohamed M.F. 2008. Characterization of some bacteria isolated from Oreochromis niloticus and their potential use as probiotics. Aquaculture 277 (1-2): 1-6.

DOI: $10.1016 / \mathrm{j}$.aquaculture.2008.02.021

Mondal S., Roy T., Sen S.K., Ray A.K. 2008. Distribution of enzyme-producing bacteria in the digestive tracts of some freshwater fish. Acta Ichthyologica et Piscatoria 38 (1): 1-8.

DOI: $10.3750 /$ aip2008.38.1.01

Mukherjee A., Ghosh K. 2014. Antagonism against fish pathogens by cellular components and verification of probiotic properties in autochthonous bacteria isolated from the gut of an Indian major carp, Catla catla (Hamilton). Aquaculture Research (Not yet assigned to issue). DOI: $10.1111 /$ are. 12676

Mukherjee S.C. 1991. Epizootic Ulcerative Syndrome in India. Pp. 22-27. In: Training Course in Fish Diseases and Control. CIFA, Bhubaneswar.

Nayak S.K. 2010. Role of gastrointestinal microbiota in fish. Aquaculture Research 41 (11): 1553-1726.

DOI: $10.1111 /$ j.1365-2109.2010.02546.x

Nikoskelainen S., Salminen S., Bylund G., Ouwehand A.C. 2001. Characterization of the properties of human- and dairy-derived probiotics for prevention of infectious diseases in fish. Applied and Environmental Microbiology 67 (6): 2430-2435.

DOI: 10.1128/aem.67.6.2430-2435.2001

Ninawe S., Lal R., Kuhad R.C. 2006. Isolation of three xylanase-producing strains of Actinomycetes and their identification using molecular methods. Current Microbiology 53 (3): 178-182.

DOI: $10.1007 / \mathrm{s} 00284-005-0285-6$

Pychyński T., Malanowska T., Kozłowski M. 1981. Tło bakteryjne branchionekrozy karpi. [Bacterial aetiology in branchionecrosis of carp.] Medycyna Weterynaryjna 37 (12): 742-743. [In Polish.]

Ramirez R.F., Dixon B.A. 2003. Enzyme production by obligate intestinal anaerobic bacteria isolated from oscars (Astronotus ocellatus), angelfish (Pterophyllum scalare) and southern flounder (Paralichthys lethostigma). Aquaculture 227 (1-4): 417-426.

DOI: $10.1016 / \mathrm{s} 0044-8486(03) 00520-9$ 
Ran C., Carrias A., Williams M.A., Capps N., Dan B.C.T., Newton J.C., Kloepper J.W., Ooi E.L., Browdy C.L., Terhune J.S., Liles M.R. 2012. Identification of Bacillus strains for biological control of catfish pathogens. PLoS One 7 (9): e45793. DOI: 10.1371/journal.pone.0045793

Ray A.K., Ghosh K., Ringø E. 2012. Enzyme-producing bacteria isolated from fish gut: A review. Aquaculture Nutrition 18 (5): 465-492.

DOI: $10.1111 / \mathrm{j} .1365-2095.2012 .00943 . x$

Ray A.K., Roy T., Mondal S., Ringo E. 2010. Identification of gut-associated amylase, cellulase and protease-producing bacteria in three species of Indian major carps. Aquaculture Research 41 (10): 1462-1469. DOI: $10.1111 / \mathrm{j} .1365-2109.2009 .02437 . \mathrm{x}$

Ross N.W., Firth K.J., Wang A., Burka J.F., Johnson S.C. 2000. Changes in hydrolytic enzyme activities of naïve Atlantic salmon Salmo salar skin mucus due to infection with the salmon louse Lepeophtheirus salmonis and cortisol implantation. Diseases of Aquatic Organisms 41 (1): 43-51.

DOI: $10.3354 /$ dao041043

Ruban P., Gunaseelan C. 2011. Antibiotic resistance of bacteria from Krishna Godavari Basin, Bay of Bengal, India. Environmental and Experimental Biology 9: $133-136$.

Sangiliyandi G., Gunasekaran P. 1996. Extracellular lipase producing Bacillus licheniformis from an oil mill refinery effluent. Indian Journal of Microbiology 36: 109-110.

Sivasubramanian K., Ravichandran S., Kavitha R. 2012. Isolation and characterization of gut micro biota from some estuarine fishes. Marine Science 2 (2): 1-6. DOI: $10.5923 /$ j.ms.20120202.01

Smith S.B., Donahue A.P., Lipkin R.J., Blazer V.S., Schmitt C.J., Goede R.W. 2002. Illustrated field guide for assessing external and internal anomalies in fish. Information and Technology Report USGS/BRD/ ITR-2002-2007.
Sugita H., Hirose Y., Matsuo N., Deguchi Y. 1998. Production of the antibacterial substance by Bacillus sp. strain NM 12, an intestinal bacterium of Japanese coastal fish. Aquaculture 165 (3-4): 269-280.

DOI: 10.1016/s0044-8486(98)00267-1

Sugita H., Shibuya K., Shimooka H., Deguchi Y. 1996. Antibacterial abilities of intestinal bacteria in freshwater cultured fish. Aquaculture 145 (1-4): 195-203. DOI: $10.1016 / \mathrm{s} 0044-8486(96) 01319-1$

Teather R.M., Wood P.J. 1982. Use of Congo red-polysaccharide interactions in enumeration and characterization of cellulolytic bacteria from the bovine rumen. Applied and Environmental Microbiology 43 (4): 777-780.

Verscheure L., Rombaut G., Sorgeloos P., Verstraete W. 2000. Probiotic bacteria as biological control agents in aquaculture. Microbiology and Molecular Biology Reviews 64 (4): 655-671.

DOI: $10.1128 / \mathrm{mmbr} .64 .4 .655-671.2000$

Vine N.G., Leukes W.D., Kaiser H. 2006. Probiotics in marine larviculture. FEMS Microbiology Reviews 30 (3): 404-427. DOI: $10.1111 / \mathrm{j} .1574-6976.2006 .00017 . x$

Walter H.E. 1984. Proteinases: Methods with hemoglobin, casein and azocoll as substrates. Pp. 270-277 (Vol. 5) . In: Bergmeyer H.-U. Methods of enzymatic analysis. Verlag Chemie, Weinheim, Germany.

Yanke L.J., Selinger L.B., Cheng K.-J. 1999. Phytase activity of Selenomonas ruminantium: A preliminary characterization. Letters in Applied Microbiology 29 (1): 20-25.

DOI: 10.1046/j.1365-2672.1999.00568.x

Zar J.H. 1999. Biostatistical analysis. 4th edn. Pearson Education, Singapore (Indian Branch), New Delhi, India.

Received: 25 June 2015

Accepted: 22 October 2015

Published electronically: 31 December 2015 